\title{
INTELLIGENT GOVERNMENTALITY
}

\section{Willem de Lint*}

Recently, within liberal democracies, the post-Westphalian consolidation of security and intelligence has ushered in the normalization not only of security in 'securitization' but also of intelligence in what is proposed here as 'intelligencification.' In outlining the features of intelligencified governance, my aim is to interrogate the view that effects or traces, and productivity rather than negation is as persuasive as commonly thought by the constructivists. After all, counter-intelligence is both about purging and reconstructing the archive for undisclosed values. In practice, what is being normalized is the authorized and legalized use of release and retention protocols of politically actionable information. The intelligencification of governmentality affords a sovereignty shell-game or the instrumentalization of sovereign power by interests that are dependent on, yet often inimical to, the power of state, national, and popular sovereignty.

On voit le politique et le social comme dépendant de contingences exclusives. Récemment, au sein des démocraties libérales, la consolidation de la sécurité et des services de renseignements de sécurité qui a suivi les traités de la Westphalie a donné lieu à la normalisation non seulement de la sécurité en "sécurisation" mais aussi des services de renseignements de sécurité en ce qui est proposé ici comme "intelligencification" [terme anglais créé par l'auteur, dérivé du mot anglais "intelligence» dans le sens de renseignements des écurité]. En particulier, ce que l'on normalise dans le but de contourner des contingences exclusives est l'utilisation autorisée et légalisée de protocoles de communication et de rétention d'information qui, politiquement, pourrait mener à des poursuites. En esquissant les traits de la gouvernance "intelligencifiée», mon but est d'interroger le point de vue que les effets ou les traces, et la productivité plutôt que la négation, est une nomenclature plus persuasive pour l'analyse : après tout, le contre-espionnage est question à la fois de purger et de reconstruire l'archive en rapport avec des valeurs non révélées. Il en résulte que l' «intelligencification» de la gouvernementalité donne lieu à une activité déceptive par rapport à la souveraineté ou l'instrumentalisation du pouvoir souverain par des intérêts qui dépendent sur et qui sont inamicaux au pouvoir de la souveraineté étatique, nationale et certainement populaire.

\footnotetext{
Department of Sociology, Anthropology, and Criminology, University of Windsor. I wish to thank the Social Sciences and Humanities Research Council for funding that enabled release time for research into intelligence. I would also like to thank Kevin Walby and Reem Bahdi for their insightful comments on an earlier draft and Steven Hutchinson, Pat O'Malley, and Aaron Doyle for inviting me to the Security in Everyday Life Workshop at Carleton University and the University of Ottawa out of which this paper emerged.
} 


\section{INTRODUCTION}

In the eyes of outside observers, Cheney is the political equivalent of a black hole, which exerts a powerful but invisible force and emits neither light nor heat that could explain the decision process. ${ }^{1}$

At times of war or existential threat, exceptionalists have it, the executive may be justified in using its security intelligence resources to further an agenda that cannot be fully revealed to those whose consent is normally required if government is to be democratically grounded. ${ }^{2}$ Today the push to reconfigure a democratic security is shaped and frustrated by this line of thought. While the regulatory terrain is still dependent on national and sovereign imperatives, the absorption of politics into the nation-state now functions where the locus of governmentality is dispersed vertically and horizontally as a "complex edifice." ${ }^{3}$ As the exploitation of protocols of non-disclosure and authorization are proliferated and further categories for the production of state intelligence are set, traditional understandings of 'intelligence' and 'security' in relation to representative liberal politics become stretched and broken.

If we bring the relation between teleological and quotidian security back into sharp focus and look forward from the emancipation of the political, what can we discover about the operation of exclusion at the back of much security talk? If the competition over authentic auspices in a networked society in end-of-ideology times is ripe for exploitation by security intelligence networks, is the intelligence function gathering up a wider purchase within and across nation-states from which to 'launch' security? Furthermore, has the 'political power' of the executive been harnessed beyond the auspices of the nation-state in the 'scavenging' of state intelligence?

What I propose to call 'intelligencification' is a form of security or governmentality; it is a colonization or fertilization of security politics via the tools of intelligence and its deferred reference to state auspices and exclusions. ${ }^{4}$ Accordingly, if the control of actionable political information through intelligence is one well-articulated exceptional practice, 'endarkened governance,' as the condition in which institutions lose their faciality as they become unaccountable in

1 David Ignatius, "Cheney’s Enigmatic Influence" Washington Post (19 January 2007) A19, online: Washington Post <http://www.washingtonpost.com>.

2 Arguments in support of the advisability and necessity of exceptional executive authority are found in thinkers ranging from Machiavelli and Hobbes to Rousseau and Locke.

3 Nancy Fraser, "From Discipline to Flexibilization: Rereading Foucault in the Shadow of Globalization" (2003) 10:2 Constellations 160.

4 From the point of view of those who serve the sovereign (through the auspices of the doctrine of national security), the 1990 s represented a dark period of conflicting and destructive tendencies. John E. McClaughlin, then Deputy Director for Intelligence of the CIA, wrote that declining intelligence budgets challenged the CIA to provide essential information to policymakers on problems on the horizon concerning "nonproliferation, counterterrorism, narcotics, and international crime" and troublesome hotspots including China, Russia, Iran, Iraq, and North Korea. (John E. McLaughlin, "New Challenges and Priorities for Analysis" (1997) 6:2 Defense Intelligence Journal 11). 
relation to their own knowledge practices, is the consequence of intelligence uptake.

This paper is launched from the gates, so to speak, of exception and will return there. If intelligencification is fed by and feeds exception, and if many heterogeneous institutions become 'endarkened' and begin to 'see like a state,' they engage in the politics of exception: making decisions about life and death and keeping the basis for those decisions discrete. While the exclusionary cut is at the heart of modern liberal state order, ${ }^{5}$ intelligence offers a negative productive power or a purposeful negation of life into history. Thus, a 'security apparatus' produces an intelligence anti-politics in which a cloaked knowledge justifies, penetrates, and at strategic moments overturns popular and state sovereignty.

In outlining the features of intelligencified rule my aim is to add to the view that effects or traces are, and productivity rather than negation is, after all, merely a choice of places to stop interpretation: information control is about purging and reconstructing the archive to shape visible government relations. That we do not care to know enough to fix them differently, or that we allow ourselves to be content with effects after all that has been said and thought about liberal democracy, is a comment on the perceived efficacy of endarkened rule. ${ }^{6}$

\section{SECURITY/POLITICS}

Over the past five or six years we have decided as a country that except in the most limited of ways, the threat to our public safety does not justify changing radically the legal basis on which we confront this extremism .... [Citizens] right to traditional civil liberties comes first. I believe this is a dangerous misjudgment. ${ }^{7}$

In the concept 'biopolitics' Michel Foucault pointed out what nowadays may seem obvious: that "life" and "living being" are at the heart of political battles and economic strategies. As he put it, "for millennia, man remained what he was for Aristotle: a living animal with the additional capacity for a political existence; modern man is an animal whose politics places his existence as a living being in question." ${ }^{8}$ That the species and its productive requirements became the object of political struggle and power knowledge relationships was radically new and

5 Nomi Claire Lazar, "Must Exceptionalism Prove the Rule? An Angle on Emergency Government in the History of Political Thought" (2006) 34:2 Politics and Society 245.

6 Intelligence, especially information control via the intelligence cycle, colonizes the field of security, and in turn, the political. By way of beginning to explore how the special knowledge of intelligence may or may not contribute, it is necessary first to mention some features of the separate 'technologies' of national security in the ideas of exceptional necessity, exclusion, and adversariality. This may reveal that the police do indeed contribute to how individuals may be visible and actionable for political rationality or security, but the special relationship with visibility that characterizes intelligence may suggest a further unfolding of political rationality.

7 Tony Blair, "Blair: shackled in war on terror" The Sunday Times (27 May 2007) online: Sunday Times <www.timesonline.co.uk/tol/comment/columnists/guest_contributors/article1845229.ece>.

8 Michel Foucault, The History of Sexuality: An introduction, vol.1 (New York: Vintage Books, 1980) at 143 [Foucault, Sexuality: An introduction]. 
emerged at a particular moment in history. However, the introduction of "life into history" corresponded not only with the rise of capitalism, but also with the development of the nation-state and the idea that population could be controlled. With a dispositif de sécurité, or biopoliticization of rule, the conditions of populations and at the same time the contingent bases of life itself could be controlled and modified.

In his seminar on the birth of the reason of state, "The Political Technology of Individuals," Foucault argued that life or living was the object of the police, which emerged between the end of the $16^{\text {th }}$ and end of the $18^{\text {th }}$ century to become a discipline and craft of knowledge about how to maximize the relation to life. The police instrumentalized political knowledge, or the capacity of the state to grow and sustain itself. In connecting individuals to the state's knowledge about its conditions and preconditions, police practices and techniques were a concrete expression of a political rationality. The police allowed individuals to be visible and actionable not only in terms of their juridical relations as abstract subjects but also as people who worked, traded, and lived. Their integration was the police problem, a problem that had not been thought of and that could not arise simply from principles of reason.

In part, Foucault wanted to make the argument that political rationality is not completely a product of political philosophy. Following the Nietzchean line, governmental rationalities work up and through "desires, aspirations, interests and beliefs." ${ }^{10}$ The problem of rule is one of reconciling the integration of individuals into totalities with extant knowledge and disciplining tools in the service of a continuous vehicle of governance, which more often than not is the state. Put another way, Foucault placed the discovery of 'reason of state' in terms of discursive, or knowledge preconditions. This idea that knowledge of individuals and populations is necessary for the state's existence is reflected in the distinction between quotidian and existential security.

Indeed, security ${ }^{11}$ has been understood and redefined according to a binary between an external and internal order. Where the direction is external, there is presupposition of a founding violence, imminent war, and the territorial separation of interests that foster or preserve a legal framework of auspices. ${ }^{12}$ Where

9 Michel Foucault, "The Political Technology of Individuals" in Luther H. Martin, Huck Gutman \& Patrick H. Hutton, eds., Technologies of the Self: Seminar with Michel Foucault (Amherst: University of Massachusetts Press, 1988) 145 [Foucault, "Political Technology"].

10 Mitchell Dean, Governmentality, Power and Rule in Modern Society (London: Sage Publications, 1999) at 11.

11 Following the constructivist reading, 'counter-terrorism' is a means of picking through this offal and bringing a familiar narrative (chasing enemies, chasing criminals) to bear on re-ordering following, especially, the demise of the inclusive and integrative model of social citizenship.

12 Didier Bigo, "Security and Immigration: Toward a Critique of the Governmentality of Unease" (2002) 27:1 Alternatives: Global, Local, Political 63 [Bigo, "Security and Immigration"]; Ole Waever, "Securitization and Desecuritization" in Ronnie Lipschutz, ed., On Security (New York: Columbia University Press, 1995); James Der Derian, "The Value of Security: Hobbes, Marx, Nietzsche, and Baudrillard" in David Campbell \& Michael Dillon, eds., The Political Subject of Violence (Manchester: Manchester University Press, 1993) 94; Charles Tilly, "War Making and State Making as Organized Crime" in Peter B. Evans, Dietrich Rueschemeyer \& Theda Skocpol, eds., Bringing the State Back In (New York: Cambridge University Press, 1985) 169. Arnold 
internal, 'social' and then 'national' security ${ }^{13}$ may be understood as a modulating technology aimed at what Foucault referred to as the integrative practices, a regulatory technology directed at "the contingency" inherent in whole populations. ${ }^{14}$ The terms 'biopower' or 'biosecurity' refer to this second value and concern the "essentially aleatory events that occur within a population that exists over a period of time." ${ }^{15}$ In sum, security is often distinguished in terms of a violent act delineating life from death ${ }^{16}$ (or in the violence of the superordinate against the subordinate) and the positive construction or revivifying of the certain political self in the perpetual reconfiguration of danger. ${ }^{17}$

Accordingly, one-way of framing the object is by way of heterogeneous life, the population function of government: things are secure when they are folded back into population. Liberal governance is measured and restricted by reference to the "factical life" 18 of the political economy of markets. Supporting liberal governance requires respect for the vitality of life, distinguishing this vitality from effects, and respecting the state's role in the periodic or regular stimulation of markets through the re-jigging of risk and the managing or modulation of contingency. Auto insurance, health care, and pension plans are illustrations of what might be referred to as quotidian modulations. However, such schemes are exquisitely responsive to a binary code, bringing into play designs of algorithms and the possibility that at the back of "factical life" a form of sovereign exception lies in wait: agencies may be compelled to distribute scarce or valued resources

Wolfers wanted to clarify the meaning of security to find out if 'national security' would be a more precise concept than 'national interest' and a better guidance for national policy-makers. He was less interested in eliminating ambiguities and inconsistencies, and more interested in demonstrating the meaning of national security, including the ambiguities it comprises. See Arnold Wolfers, Discord and Collaboration: essays on international politics (Baltimore: Johns Hopkins University Press, 1962) at 147-149.

13 Mark Neocleous, "From Social to National Security: On the Fabrication of Economic Order" (2006) 37:3 Security Dialogue 363.

14 Michael Dillon, "Governing Through Contingency: the Security of Biopolitical Governance" (2006) xx Political Geography 1. Security is often understood as a self-perpetuating discourse. Indeed, aleatory effects, violence, exclusion, monsters, ghosts - the wide frame of political possibility from which 'the other' is chosen and the political subject is shaped - depends upon the contrary view that chaos or unknown unknowns is not without but within.

15 Michel Foucault, Society Must be Defended: lectures at the Collège de France, 1975-1976, 1st ed. by Mauro Bertani \& Allesandro Fontana, trans. by David Macey, (New York: Picador, 2003) at 246 [Foucault, Society].

16 In decisionist and republican exceptionalism nation-state founding and maintenance is a kind of existential emergency that can be made to play by the rule of law only inasmuch as legality itself suppresses expectations of transparency, universality, and justice (cf. Lazar, supra note 5). This is in accord with Benjamin's argument that violence is a necessary precursor to law and Derrida's (See especially, Of Grammatology, trans. by Gayatri Chakravorty Spivak (Baltimore: John Hopkins University Press, 1976) suggestion that political identity, like self-identity, is dependent on linguistic violence. See Marcus Bullock and Michael Jennings, eds., Walter Benjamin: Selected Writings, Volume 1 1913-1926 (Cambridge: Belknap Press of Harvard University Press, 1996) 236-253.

17 See Barry Buzan, Ole Waever \& Jaap de Wilde, Security: A New Framework of Analysis (Boulder: Lynne Rienner Publishers, 1998) at 21. As they summarize, "by saying 'security' a state representative declares an emergency condition, thus claiming a right to use whatever means are necessary to block a threatening development."

18 Dillon, supra note 14 at 2. 
or services, and to do so deploying discrete evaluations. Beginning from the position of biopolitics and accepting the dis-aggregation and re-aggregation of populations, an underlying necessity - the necessity of organizing populations according to those scarcities whatever the technological mediator - brings us back to the teleological or existential question of war and opposition.

And now we are at a point where it is not the state but the security apparatus or network that stands in for the necessary knowledge of individuals and groups and the methods of their incorporation into a totality. Knowledge and practices of the security network see past the state and contest dominion over who needs to be excluded and who must be sacrificed for its own maintenance. In addition, slippage of the individual and population across borders produces further dis-aggregations (of identities, groups, cohorts) that are mediated by political rationalities through practices that do not any more 'see' the problem of contingent groups of people but rather contingent information bundles. At the heart of this is the intelligence operation, built bottom up from the requisite of existential rights and exclusionary practices but now capturing or arresting the flow of contraband data bundles. By way of beginning to explore how the special knowledge of intelligence is now a practice that pushes a political rationality, it is necessary to mention some features of the separate 'technologies' of national security in the ideas of exceptional necessity, exclusion, and adversariality.

\section{A. The Crucible of the Other}

Observance of this distinction between external and internal mandates (police-law enforcement versus security intelligence, for example) sets up security as a binary ${ }^{19}$ that is predicated on national territorial exclusivities (subject-object, enemy-friend) and, in the modern liberal variant, the constitutional construction of the private self in adversarial relations with authority. This second dimension is the consequence of adversarial politics.

'The political' is conceived, as per Hannah Arendt, as a relatively boundless space $^{20}$ and the essence of pluralist politics is the occupation of that space by

19 Waever, supra note 12; John Mearsheimer articulates an offensive realist world where states ward off existential uncertainty through boundary-constituting "discourses of danger." See John J. Mearsheimer, The Tragedy of Great Power Politics (New York: W.W. Norton, 2001) cited in Jennifer Mitzen, "Ontological Security in World Politics: State Identity and the Security Dilemma” (2006) 12:3 European Journal of International Relations 341 at 362. Rob Walker argued that the discourse of the international is dependent on an inside/outside dialectic (Rob Walker, Inside/Outside: International Relations as Political Theory (Cambridge: Cambridge University Press, 1993).

20 Hannah Arendt, "Philosophy and Politics" (1990) 57:1 Social Research: An International Quarterly of the Social Sciences 73; See also Chantal Mouffe, On the Political, 1st ed. (New York: Routledge, 2005); Ernesto Laclau \& Chantal Mouffe, Hegemony and Socialist Strategy: Towards a Radical Democratic Politics (London: Verso, 1985). The Arendtian political is a site for the display of courage and uniqueness (a chance to create beauty and an understanding of human dignity that "transcend[s] the life-span of mortal men." (Hannah Arendt, The Human Condition (Chicago: University of Chicago Press, 1958) at 55) It is the actualization of a hypothetical, hopeful, and yet also dangerous subject (Julia Kristeva, The Powers of Horror: An Essay on Abjection (New York: Columbia University Press, 1982)), and discovery of the infinite scope of humanity, founded on plural interactions and the opening up of "a space for reciprocal self-evaluation." (Adriana Cavarero, "Politicizing Theory" in Stephen K. White \& J. Donald 
adversarial contest. ${ }^{21}$ Politics draws on the idea of an original unbounded unity cut into unequal divisions of subordinate/superordinate or bare/political. The first cut is on the crucible of the righteous, unified nation state ${ }^{22}$ by referencing the necessity of war and the capacity to wage it. The second, is the transparency of agonistic or open contest or conflict that governs the manner or propriety of the pursuit of liberal law and politics. Even in much current thinking about political identity the foundation of what might be called 'the exclusive cut' is maintained as a norm of internal administration. ${ }^{23}$ Following this, politics is deployed to fix parameters or knowledge about political identity ${ }^{24}$ in an explicitly delimiting function of information control. What is being normalized is not just the exception ${ }^{25}$ and effects but a whole array of palpable measures that make the collection, analysis, and distribution of information the crucible of modern liberal government. Today the lack of certainty between boundaries and the absence of clear designations between inside and outside exacerbates a condition of ambiguity and destabilization. In part, this collapse is a result of the re-bordering of the political of the nation-state in the context of the push for unencumbered commerce and trade. In another part, it is the consequence of the dissolution of jurisdictional differences. ${ }^{26}$

Moon, eds., What is Political Theory? 1st ed. (London: Sage Publications, 2004) 54 at 63).

21 Agreement on antagonism connects the conservative and radical view of security politics.

22 In Arendt's language security politics limits political subjects to a restricted existence of "unfreedom and work" rather than beauty and immortality.

23 See also Andrew W. Neal, "Foucault in Guantanamo: Towards an Archaeology of the Exception" (2006) 37:1 Security Dialogue 31. In late or high modern society, the relationship between intelligence, knowledge, and governance is also conditioned by the fearful response to the breakaway quality of modern-life (see Anthony Giddens, The Consequences of Modernity (Stanford: Stanford University Press, 1990)) and the dread of catastrophe (see Ulrich Beck, Risk Society: Towards a New Modernity (London: Sage Publications, 1992)) Indeed, following the interrogation of the modern rationalist absorptive project and the problem of doubt, a measure of effective rule is the uptake of 'the look' of political security. This is found most emphatically in Jean Baudrillard, The Gulf War Never Happened (Oxford: Polity Press, 1995) and reflected in "synoptic power" amendments to Foucault (see Thomas Mathiesen, "The View Society: Michel Foucault's 'Panopticon' Revisited” (1997) 1:2 Theoretical Criminology 215). Having abandoned efforts to get behind discursive formations, a post-Foucauldian corpus cuts the social and political by discerning likeness among practices and effects rather than intentions and interests.

24 Hänninen says that politics is therefore best conceived of as "living with ambiguity." (See Sakari Hänninen, "The Ghost of Politics in the Soft Machine" in Sakari Hänninen \& Jussi Vähämäki, eds., Displacement of Politics (Jyväskylä: SoPhi University of Jyväskylä, 2000) 27 at 27) It may be added that Arendt's political space and the adaptation of it in radical democracy already depends on a clear distinction or bounded space in the sense of assuming the configuration, which is already too narrow and confined. In a globalized post-regulatory terrain enemies and antagonists have already been absorbed. That being said, it is also clear that the realist presumption of international relations permits the colonization of the political in a way that is contrary to its compatibility with pluralist democracy.

25 Cf. William E. Scheuerman, Between the Norm and the Exception: the Frankfurt School and the Rule of Law (Cambridge: Massachusetts Institute of Technology Press, 1994).

26 Nancy Fraser notes that "social ordering is no longer nationally bounded, nor correlated with a national state, nor centred in any single locus of coordination. Rather, the locus of governmentality is being unbundled, broken up into several distinct functions, and assigned to several distinct agencies which operate at several distinct levels, some global, some regional, 
If there has been a bifurcation according to which the internal affairs of the state are guided by the pastoral order (care of each and all, maximization of the economy, cultivation of expectations through predictabilities of the rule of law, ${ }^{27}$ attention to quotidian needs), and external affairs are conditioned by the existential order (each against all, territorial imperatives, relations of unease), ${ }^{28}$ today we see a blending of the exceptional and quotidian order. This is evident especially in the internal operation of security and police. If sovereign law still requires subjects that are differentiated in a process of exclusion or, as per discipline, reform, managing the beast within has required regulatory and preventative governance or an articulation between sovereignty and biopolitics, or traffic regulation that distinguishes licit from illicit flows.

Following Foucault, this may be analysed as the displacement of politics by the power-knowledge of security networks. ${ }^{29}$ It may be seen as a stretching or breaking of political rationality or the concrete expression of connective tissue between the state's knowledge about its conditions and preconditions, and police practices and techniques. This is apparent in the reversal of the predicate, as exclusions at the level of the quotidian or everyday life are made to satisfy the appetite for exception. Indeed, the rationale for a study of intelligence in government agencies is to show how the politics of exception, the power to make sovereign decisions about life and death, is traveling with state intelligence information to heterogenous organizations alongside or inside quotidian security strategies. In the broadest sense of the term, the police do indeed contribute to how individuals may be visible and actionable for governmentality or security, but the special relationship with visibility that characterizes intelligence may suggest a further unfolding of political rationality.

\section{B. Order/Visibility}

There is a further iteration of practices that articulate objects and subjects of rule for consistency with the modality and modulations of security. That is to say, if security is embedded in the practice of police, it might be argued that

some local and subnational." (supra note 3 at 167) In fact, such a representation avoids the problem of the actual ownership, identity, and nature of a sovereignty that can no longer be recognized only in the light of state borders. Because it hides its multiple and fuzzy identities behind the entangled network of relations and flows which run across the planet, showing itself in the most different ways, times and places, while it multiplies and diversifies its 'supply' of borders in order to face a 'demand' of control which is growing more and more complex, subtle, and variegated.

27 Didier Bigo uses the term "mobius ribbon" to capture the phenomenon in which the present period is one in which inside and outside do not have clear meanings. (See "The Mobius Ribbon of Internal and External Security(ies)" in Mathias Albert, David Jacobson \& Yosef Lapid, eds., Identities, Borders, Orders: rethinking international relations theory" (Minneapolis: University of Minnesota Press, 2001) 91.

28 Mariana Valverde, "Police, Sovereignty, and Law: Foucaultian Reflections" in Markus D. Drubber \& Mariana Valverde, eds., Police and the Liberal State (Stanford: Stanford Law Books, 2008) 15; Bigo, "Security and Immigration", supra note 12.

29 Consequently, the immigrant, as per Bigo, "Security and Immigration", supra note 12, is primarily a useful object for the use and experimentation of new technologies rather than an object of strong interest in border protection. 
intelligence is a further unfolding of police practices. We might expect it will be attended by a distinctive set of knowledge preconditions. To follow this point forward a note about discursive order and visibility may be helpful.

What Foucault has called "systems of exclusion" refers to the variety of practices that maintain a particular body of knowledge or govern the will to knowledge. ${ }^{30}$ These include the mechanisms that protect the base of assumptions or the founding affirmations and the institutional and professional self-understandings that maintain institutional knowledges. It also includes internal rules that arrange principles of classification, ordering, and distribution and the distinction between primary and secondary texts. ${ }^{31}$ In outlining the function of disciplines, Foucault ${ }^{32}$ noted the priority of building criteria, or an endless supply of fresh propositions that fit into the hierarchical order of the field, over meaning or hermeneutics. Thus, "disciplines constitute a system of control in the production of discourse, fixing its limits through the action of an identity taking the form of a permanent activation of the rules." ${ }^{33}$ 'Rarefaction' accords conditions that must be met for subjects to be qualified to speak. 'Fellowship' preserves and reproduces the stipulations on the circulation of discourse in the maintenance of its truth claims. ${ }^{34}$ Building criteria, rarefaction, and fellowship in disciplinary development and elaboration will be contoured by the power relations attending technologies of government. Mechanisms by which whole societies might record and archive knowledge as sufficiently stable, mobile, comparable, and combinable were referred to by Bruno Latour as "inscription devices" and "centres of calculation." ${ }^{35}$ In the information age, practices of governance involve the nonarchiving of key information and the legitimation of non-disclosure and collection (and other) practices. ${ }^{36}$

30 Foucault identified the "three great systems of exclusion" that govern discourses as prohibited words, division of madness, and the will to truth. See Michel Foucault, "Orders of Discourse" (1971) 10:7 Social Science Information 11 [Foucault, "Discourse"].

31 Ibid. at 12-13.

32 Ibid. at 15.

33 Ibid. at 17.

34 Ibid. at 17-18. In comparing knowledges, Fuchs and Ward argue that in "highly decentralized fields with weak resources for producing facts" there are permanent crises in social solidarity, organizational cohesion, and professional communication. (Stephan Fuchs \& Steven Ward, "What is Deconstruction, and Where and When does it take Place?" (1994) 59 American Sociological Review 481 at 485) Radical deconstruction is more common in such fields, as is scepticism, relativism, and anti-foundationalism. In contrast to the strong resources and professional networks for producing facts and objective knowledge of the physical sciences and most of law, social sciences including, we may claim here, security and police studies, are highly fragmented in self-contained schools that cannot be readily unified on methodologies or truthclaims and are, consequently, acutely susceptible to external political agendas and ideologies. This is susceptibility beyond that already provided by sheer resource dependency.

35 Nikolas Rose \& Peter Miller "Political Power Beyond the State: Problematics of Government" (1992) 43:2 British Journal of Sociology 172 at 187.

36 Some prominent recent conceptualizations of the conduct of conduct more or less follows the double-bind of the Foucauldian diagram (See Michel Foucault, The History of Sexuality, vol. 3 (New York: Vintage Books, 1976) at 140 [Foucault, Sexuality]): risk (See Pat O’Malley, "Volatile and Contradictory Punishments" (1999) 3:2 Theoretical Criminology 175), insurance (See Richard V. Ericson, Aaron Doyle \& Dean Barry, Insurance as Governance (Toronto: University of Toronto Press, 2003)), information (See Mark Poster, The Mode of Information: 
"Le dispositif de securite" is an assemblage that includes a logic of sovereignty and the population, aggregate, or "social security" designation. It is a heuristic device that contests the realist idea that rules follow the sovereign exception, installing instead a more preeminent role for practices that arise between rationalities and technologies of the self. However, what I am calling 'intelligencification' depends on exceptionalism, most importantly the modulation of the visibility element of the dispositif. My argument is that exceptionalism also girds population and quotidian security. Visibility builds and is built into the dispositif and the security assemblage. This has consequences as to how politics and security may be thought up. That is to say that systems of exclusion are not prior to the 'faciality' of discursive formation (that is why the building of patterns by looking for effects or by inspecting the archives of subordinate narratives). On the contrary, the style or modality of government may be a reading up of the approved or superordinate archive; a reading that not only cannot be fully informed, but at a deep level builds in the expectation that information is endarkened. This element of the dispositif of liberal democratic states is what I propose to highlight here.

\section{SECURITY/INTELLIGENCE}

Following this argument, we may conceptualize security intelligence as about organizing knowledge for a politics of antagonism (that contemplate the liminal or the breaking and remaking of boundaries and re-inscribe (or re-determine) the life of politics with exclusive identity). ${ }^{37}$ Security mechanisms are "installed around the random element inherent in a population of living beings so as to optimize a state of life." ${ }^{38}$ They foster political identity by postponing or con-

poststructuralism and social context (Cambridge: Polity Press, 1990)) and contingency (See Dillon, supra note 14) follows biopolitics; crime (See Jonathan Simon, Governing Through Crime: How the War on Crime Transformed American Democracy and Created a Culture of Fear (New York: Oxford University Press, 2007)), security (See Lucia Zedner, "Too Much Security?” (2003) 31:3 Int'l J. Soc. L. 155), control (See Gilles Deleuze, "Postscript on the Societies of Control" (1992) 59 October 3; David Garland, The Culture of Control: Crime and Social Order in Contemporary Society (Chicago: University of Chicago Press, 2001)), surveillance (See David Lyon, Surveillance Society: Monitoring Everyday Life (Buckingham: Open University Press, 2001)), waste (See Zygmunt Bauman, Wasted Lives: Modernity and its Outcasts (Oxford: Polity, 2004)), unease (See Bigo, "Security and Immigration", supra note 12) and exclusivity (See Jock Young, The Exclusive Society: Social Exclusion, Crime and Difference in Late Modernity (London: Sage Publications, 1999) at 1-29) follows anatomo-politics.

37 In talk of law, we also have a story of its "beleaguered foundation" (Andrea Brighenti, "Dogville, or, the Dirty Birth of Law" (2006) 87:1 Thesis Eleven 96) in custom, myth, or fetishism. As pointed out by Brighenti (at 106), the mobility of the excluded is also assured through the outlawing of their economy because the economic subject "is no longer wholly external to the community." The maintenance of legitimate and illegitimate spheres of commercial activity (in drugs, in support of politics) is a legacy of this 'dirty birth.' The founding of law in original acts of violence excludes and puts in place a legacy of subjects who are then too dynamic or active to incorporate. This is also a discovery of libertarian thinkers following Locke (e.g. Robert Nozick, Anarchy, State, and Utopia (New York: Basic Books, 1974)).

38 Foucault (as per Dillon, supra note 14 at 5) goes on to say that a "certain threshold of modernity is reached when it wagers the life of the species on its political strategies" and that "the general economy of power" is in the process of becoming an order of security with society dominated by security technologies that put "le destin biologique in question." (Foucault, Society, supra note 15 at 246). 
taining the collapse of biopolitics into a "zone of indistinction." ${ }^{39}$ Security policies emerge as affordances ${ }^{40}$ to the political community. Internally and externally the policy question is where and against whom the cut of politics is to be made ${ }^{41}$ The necessary hard distinction or value is likely to be found where power intersects with knowledge in centres of calculation.

Intelligence is knowledge production, the visibility of which is modulated by and may also be installed to protect the exclusionary cutting (sovereignty) of an executive authority. ${ }^{42}$ The building of the knowledge and the discipline - and to some extent the craft - of intelligence is restricted according to citizenship, loyalty, associations, memberships, etc., and vetted through restricted commissions or privileged access to the knowledge pool. Like the policing function, intelligence is relatively independent of political leadership. It is driven by the building criteria, including the deployment of archives, and the array of and control over sources and methods. Authorship or data entry is rigorously controlled and the combination of data is restricted through tight compartmentalization, itself part of the mode of inscription in the intelligence enterprise. Further validation is predicated on a hierarchical filtering ${ }^{43}$ via security clearances, trust networks, etc. ${ }^{44}$ that feature cross-referencing or vouching of privileged sources and methods that already flow from political limiters (political party affiliation, club or organization membership, loyalty measures, etc.).

Intelligence actionability requires that information has passed through the intelligence cycle and has been recoded as exclusive knowledge. ${ }^{45}$ Intelligence

39 According to Agamben's reading, this is because behind nation-state politics is a sovereign power that continuously achieves the transmogrification of sacred life into bare life. (See Giorgio Agamben, Homo Sacer: Sovereign and Bare Life, trans. by Daniel Heller-Roazen (Stanford: Stanford University Press, 1998) at 122) [Agamben, Homo Sacer]. Put another way, bare life connects the anatamo-politics of the body and the biopolitics of population. Bare life is "held in abeyance" as a malleability of the contemporary body and sovereign power is parasitic on the biopolitics or control via categorizations or management of population (Lazar, supra note 5 at 262).

40 Mike Michael \& Arthur Still, "A Resource for Resistance: Power-Knowledge and Affordance" (1992) 21:6 Theory and Society 869.

41 In the currency of the times, the political, the field of political power relations, is cut against redistributive welfare 'gluttony:' the war is on drugs, on crime, on political ambiguity itself, in the service of re-marketization ventures. This pushes economies (drugs, military, primary industries) and political actors into black.

42 Nico Stehr, "The Social and Political Control of Knowledge in Modern Societies" (2003) 55:4 International Social Science Journal 643.

43 Cf. Jean-Paul Brodeur \& Benoît Dupont, "Knowledge workers or 'knowledge' workers?” (2006) 16:1 Policing and Society 7.

44 Willem de Lint, Daniel O’Connor \& Ryan Cotter, “Controlling the Flow: Security, Exclusivity, and Criminal Intelligence in Ontario" (2007) 35:1 Int'l J. Soc. L. 41.

45 It may be relatively autonomous but is also prone to partisan and ideological or hegemonic values: intelligence, specifically in the intelligence cycle, includes the identification of targets and the choice between a variety of utilities (how clandestine? how countered?) and such choices are a product of the load bearing capacity of the field. Bigo, "Security and Immigration", supra note 12 at 74, sees as a "field effect" the ability of security professionals to secure claims of threat without needing to have this validated independently or from without. However, if history serves as a guide, it shows us that state intelligence resources are ideologically disposed and often utilized to prepare the ground in 'pump and dump' schemes: they deploy the information 
is 'disciplined' through flow controls, ${ }^{46}$ through centralization and its visibility modulation, and the impenetrability of the most actionable information to all but the most dominant in the information chain. Unlike pure violence, the exclusionary tactic of intelligence manipulates the processes of information control, which is conceptualized by Wilsnack ${ }^{47}$ as including espionage, or the obtaining of information against their will of targets, secrecy, or the keeping of information from others who may be able to deploy it in their interests, persuasion, or the dissemination of information to coerce consent, and evaluation, or the maximization of the exploitability of obtained information. The validity of intelligence in the exploitation of knowledge exclusivities, ${ }^{48}$ unlike legal knowledge, does not require an attendant record of the coercion used to achieve it. ${ }^{49}$

edge of secret, exclusive knowledge to prepare sites for mostly private investment of public monies that serve the interests of key private corporate constituents and, most importantly, their confidential shareholders. Intelligence functions as a cover for the exploitation of public resources for private corporate profit and initiatives that otherwise, as per Tilly, supra note 12 and Benjamin (Bullock \& Jennings, supra note 16) would be deemed illegal, immoral, and unprofitable.

It might be worthwhile to make note of intelligence not only as a mode of knowledge production but also as a mode of knowledge consumption and simulation, as follows the postmodern turn. Accordingly, excess and waste rather than economic production (Baudrillard, supra note 23) and blank parody rather than satire (Fredric Jameson, Postmodernism, or, The Cultural Logic of Late Capitalism (Durham: Duke University Press, 1991)) is the appropriate stance. According to Baudrillard's view, real events are modeled and then transpire in the real to be produced by simulation apparatuses like the media. In the reversal of the modeling of the real through representation devices, in the post-modernist understanding the map precedes the territory in the precession of simulacra. Thus, journalists do not present news but create it, modeling the real in pretend reports that comprise the reality to be reported. Social control, on this model, is secured by seizing the means of simulation and controlling images. Thus, for example the Gulf War was modeled through the media, and public relations firms accordingly have been pivotal: "this war is being brought to you by Rendon Group;" the Bush administration paid $\$ 1.6$ billion to various public relations firms to plant spin in news stories and other such efforts from 2003 to the second quarter of 2005. ("Update: Prepacked News" The Washington Post (14 Feb 2006) A13.) Following this, security demonstration projects (Willem de Lint, Sirpa Virta \& John Deukmedjian, "Simulating Control: A Shift in Policing?” (2007) 50:12 American Behavioral Scientist 1631) showcase the sovereign power to cut biopower into homo sacer, the message or the meaning conveyed being a kind of nostalgia for such acts of sovereignty as something more than blank parody.

46 Anthony Giddens, A Contemporary Critique of Historical Materialism: the Nation State and Violence, vol. 2 (Cambridge: Polity, 1985).

47 Richard W. Wilsnack, "Information Control: a conceptual framework for sociological analysis" (1980) 8:4 Journal of Contemporary Ethnography 467.

48 For Agamben, Homo Sacer, supra note 39, it is the necessary exceptional or sovereign practice of cutting the sacred in the act of discovering bare life, a cut whose methodology or sources and methods cannot be exposed without undermining the strength or power of the sovereign. For Mouffe, it is a cut that continuously produces a new antagonism from agonism. (See supra note 20).

49 Andrew Green, "How the Criminal Justice System Knows" (1997) 6:1 Soc. \& Leg. Stud. 5.The division of intelligence capacity from the weak claims on authority of a particular standing executive is found in the distinction between the modern separation of truth and power and high modern 'play' beyond this separation. Thus, if the manipulation of meaning prefers a vacuum (of information or knowledge), bureaucratic surveillance is the capacity to dominate and coerce by structuring the flow of authoritative information or in producing low visibility 
In sum, intelligence recycles the methods of exemption and exceptionalism. It is evaluated in terms of being successful in addressing the problem of the unknown, unknowability, and indeterminacy itself. ${ }^{50}$ It finesses systems of exclusion to restrict or manipulate the play of knowledge (its contingent representations). ${ }^{51}$ The mode of inscription involves calculated deception about methods and sources, and the reception or review of informational products.

If security is installed around the random elements as a practice of biopower ${ }^{52}$ and intelligence is a means of restricting or manipulating the play of security knowledge (its contingent representations) on a politicization of social and economic concerns then governing through intelligence is the cutting or re-cutting of the political through information management, or the control of the conversion of politically actionable information from commonality into exclusivity. The management of security intelligence through processes of information control (in the choice of collection, the stipulation on analysis, judgments about dissemination) is already a function of exceptional necessity. 'Petty sovereigns' more or less protected from an autonomous judicial check routinely make decisions (albeit restricted) about the flow of information about security that then qualifies mobility and other freedoms and pulls leaders themselves on the security tether. The preconditions of political life and death are modulated through intelligence (at least, that is the intent). Accordingly, intelligence extends beyond the parameters of security and may produce an apparatus of rule that allows for the politics of exception to travel outside the traditional decision-making ambit of the sovereign into other organizations. The result is not merely a breach of the classical liberal contract following 'government by consent.' The intelligencification of security (as governmentality) proceeds in large measure on the strength of the silent work that is done against the subordinated supplement: it cannibalizes openness, free exchange, and common good; it is a parasitic on public, common, or everyday knowledge. ${ }^{53}$

knowledge by design. As we shall see, this depends on various horizontal (compartmentalization, third party rule) and vertical (classifying authority) regulatory practices.

50 Jef Huysmans, "Security! What do you mean? From concept to thick signifier" (1998) 4:2 European Journal of International Relations 226. This ties exceptionalism to exclusion and exclusion to security intelligence. It follows that the drive to tease uncertainty and ambiguity out of the lifeworld is a common denominator of security and politics. As for security policy, there is a paradox of political identity: political identity relies on the threatening force of the other, but security policy reifies and then organizes resources to consolidate, enumerate, demonstrate action on this threat; if the policy is successful and the threat eliminated, the political identity is damaged and may collapse altogether Threat construction shapes security and expectations of political identity so that the political spectrum is coloured by a stark existentialism; as was foretold in Rousseau's Emile, both the radical right and the radical left arc towards one another sharing much in common, most dramatically against pluralistic and pragmatic viewpoints. Huysman at 239.

51 The overriding concern is also that contingency is the source and object of these practices.

52 Dillon, supra note 14.

53 As an illustration, the al-Qaeda network was a "convenient instrument," an "unpredictable intelligence asset" of Western statecraft "for the orchestration of illegal and corrupt covert operations." Whether that included 9-11 remains in doubt. Less doubtful was its recruitment in the 1993 World Trade Centre (WTC) bombing. A key organizer of the WTC bombing, Emad Ali Salem, an Egyptian intelligence officer and at that time a paid Federal Bureau of Investigation 


\section{INFORMATION CONTROL/ENDARKENMENT}

The fundamental principle of intelligence services and intelligence investigations is the control of information. ${ }^{54}$

As in totalitarian states, in liberal democracies order is achieved by marking, distinguishing, and excluding identities through the channeling of information and knowledge, particularly knowledge about the art of government. Routine subordinations or information subservience is maintained through systems of exclusion, including the base assumptions and founding affirmations, building criteria, and maintenance of fellowship and rarefaction mechanisms. And if the power of intelligence is the manipulation of information exclusion and inclusion, two distinct processes may be discerned. First, there are overt information preservation processes and mechanisms to produce and maintain the network of authorized knowers. Second, there are a range of covert information release processes and mechanisms to maintain the subordination of unauthorized or common knowers.

\section{A. Authorized Knowing: Information Exclusion Protocols and Networks}

Strategic information control depends on the deterrence of unauthorized dissemination through non-disclosure policies, protocols, and strategies. There are several mechanisms by which information is prevented from freely circulating. Firstly, there are classification and vetting processes by which the dissemination of documents (classification) and people (vetting and screening assessments, indoctrination) is restricted according to category or clearance level. Raw intelligence and analysis is subject to classification and persons are vetted and/or indoctrinated to structure their relationship with official material. Two key mechanisms that operate to push non-disclosure is the principle that information is disseminated on a 'need to know' basis ${ }^{55}$ and that it is protected with reference to the inviolability of 'sources and methods.'

Between 6 and 7 million documents were stamped 'classified' in 1997 in the

(FBI) informant (37), later acted as a key government witness, providing more than 1000 tapes of recorded conversations of Sheik Omar Abdel Rahman (the blind Sheik, close companion of Osama bin Laden), 'mastermind' of the WTC bombing, a 'valuable asset' according to US intelligence officials) covering the al-Qaeda cell's plans prior to the attack. Even more intriguing, it is alleged that the FBI had precise prior knowledge of the bombing because it was providing material resources, abandoning at the last minute a plan to substitute fake powder in the bomb for the real thing. (See Nafeez Ahmed, The War on Truth: 9/11, Disinformation, and the Anatomy of Terrorism (New York: Olive Branch Press, 2005) at 31,37-39).

54 The Honourable Frank Iacobucci, Q.C. Commissioner, Internal Inquiry into the Actions of Canadian Officials in Relation to Abdullah Almalki, Ahmed Abou-Elmaati and Muayyed Nureddin (Ottawa: Queen's Press, October 2008) at 69, para. 22. online: Iacobucci Internal Inquiry $<$ http://www.iacobucciinquiry.ca/en/documents/final-report.htm>.

55 See Exec. Order No.13,292, sec. 6.1(z), 68 Fed. Reg. 15,315, 15,332 (28 March 2003) (restricting access to National Security Information to those who have an appropriate clearance and a "Need-to-know" the information basis, which is at the sole discretion of authorized holders of the information). 
US. ${ }^{56}$ The Information Security Oversight Office, which supervises the government's classification system, recorded a rise from 9 million classification actions in 2001 to 16 million in $2004 .{ }^{57}$ The volume of federal government information deemed "confidential" also went up precipitously, from 8 million in 1999 and more than 23 million in 2002. ${ }^{58}$ Meanwhile, the volume of declassification dropped from 204 million pages in 1997 to 28 million in $2001 .^{59}$ After the end of 2006, a statutory program of automatic declassification for records with 'permanent historical value' came into effect and agencies declassified 37,647,993 pages, a 27 percent increase over the 2005 number. However, $\$ 8.2$ billion was spent on securing classified information, up from $\$ 7.2$ billion in $2001 .^{60}$

Unclassified, public information may be restricted in its dissemination by government officials who are given wide authority to declare information beyond public reach. In 2006 some 4,042 federal workers were given 'original classification authority' (OCA) with the power to classify a document 'top secret,' 'secret,' or 'confidential.' In addition, about 3 million people were derivative classifiers. ${ }^{61}$ The United States Government Accountability Office (GAO) also identified 56 types of restrictions on unclassified information that fall outside the national security classificatory system, under the heading 'Controlled Unclassified Information' (CUI) or 'Sensitive But Unclassified' (SBU). The number of invocations of 'state secrets,' a unilateral declaration by the executive branch, also increased from being used once every 4 years between 1953-1976 to 6 times per year after $2001 .^{62}$ Claims of 'executive privilege' have remained steady.

Classification is anchored to a statutory framework, including official information legislation, by which unauthorized disclosures may result in criminal prosecutions and allowable disclosures are vetted through secrecy bureaucrats. ${ }^{63}$ Under this regime, Attorney General John Ashcroft directed federal agency heads

56 Daniel Patrick Moynihan, Secrecy: the American experience (New Haven: Yale University Press, 1998).

57 “Secrecy Report Card 2007”, online: Open The Government: Americans for Less Secrecy, More Democracy <http://www.openthegovernment.org> ["Secrecy Report"].

58 Joe Feuerherd, "Top Secret: Critics say Bush refusal to release records is more about politics than security" National Catholic Reporter: the Independent Newsweekly (09 January 2004), online: National Catholic Reporter <http://natcath.org>.

59 Scott Shane, "Since 2001, Sharp Increase in the Number of Documents Classified by the Government” The New York Times (3 July 2005), online: The New York Times <http://www. nytimes.com>.

60 "Secrecy Report", supra note 57 at 6.

$61 \mathrm{Ibid}$.; With regard to vetting, security clearance, or screening assessments, the degree of inquiry into the character and identity of persons is dependent on the level of access sought for them. Thus, inquiries are more perfunctory as one scales down the secrecy wall from 'top secret' to 'confidential' classification categories. An additional stack is that of information produced on individuals who have been subjected to security clearances.

62 Ibid. at 13.

63 Statutory provisions also allow the classification of documents for set periods of time. Already in the 1950s, the Coolidge Committee (1956), the Wright Commission (1957), and the Moss Subcommittee (1958) argued the point that over-classification was becoming a problem, one that represented a danger to national security (Wright 1957) and needed to be punished (cf. Moynihan, supra note 56). See for example, Exec. Order No.13, 292, sec. 6.1(z), 68 Fed. Reg. 15,315, 15,332 (Mar. 28, 2003). See Makky v. Chertoff, 489 F. Supp. 2d 421 (D.N.J.) aff'd by 541 F. 3d 205 (3d Cir.) (N.J.) [Makky]. 
to "search for and use any legal authority for denying access to records under the FOIA [Freedom of Information Act]." ${ }^{\prime 44}$ In 2006, the number of FOIA personnel was down $10 \%$, while the number of FOIA requests processed fell by $20 \%$, the backlog tripled and the cost per request was up $79 \% .{ }^{65}$ In the meantime, Ashcroft was undertaking a "comprehensive, coordinated Government-wide, aggressive, properly resourced, and sustained effort to deal with the problem of unauthorized disclosures" ${ }^{166}$ beyond what is covered by the Espionage Act. ${ }^{67}$

The classification or exclusion of intelligence is also vetted through political oversight. These include parliamentary or congressional or senate committees, inspector generals, commissions of inquiry, Parliamentary Question Period, and various other bodies and institutions, including protections on speech and fair comment. As has been variously argued, ${ }^{68}$ these are structurally unsound because they are balanced against information disclosure. Oversight agents themselves (legislative or executive) are vetted and indoctrinated and in the process 'captured' by security intelligence discourse. Further capture takes place through the price tag of political campaigns: in 2006 a successful Congress run was estimated at $\$ 1.3$ million and a successful Senate run at $\$ 9.6$ million. ${ }^{69}$ At the same time, and in the rarefied atmosphere of big money politics, offices like Inspector Generals, parliamentary committees, and ombudspersons or commissioners are relatively vulnerable lone wolves. As Robin Ramsey puts it, "no one with an ounce of career-mindedness is going to take a critical interest in the security agencies." Given the available cover of "need-to-know" and protected sources and methods, the balancing that committees and oversight agencies do will be skewed in the direction of non-disclosure. Judicial and legislative oversight is additionally hampered by a reticence to tread on the perceived primacy of the executive in security matters. ${ }^{71}$

645 U.S.C. $\$ 552$ (2002); Electronic Privacy Information Centre, 9.05: 2 http://epic.org/. It has been estimated that 5 million e-mail messages largely related to the administration's liaison with the Department of Justice have disappeared from White House computers. ("White House Shell Game," Editorial, The New York Times (24 August 2007), online: The New York Times <http://www.nytimes.com>).

65 "Secrecy Report", supra note 57. Meanwhile, Patrick Fitzgerald, while acting as special counsel in the CIA leak investigation of Valerie Plame, appeared to discover the 'greying' of official information or the 'laundering' of emails relating to official decision-making through their archiving under the private auspices of the Republican National Congress, an apparent end-run around the FOIA.

66 John W. Dean, "Bush's Unofficial Official Secrets Act: How the Justice Department Has Pushed to Criminalize The Disclosure of Non-Security Related Government Information" Find Law (26 September 2006), online: Find Law <http://www.findlaw.com>.

67 ch. 30 , tit. I $\$ 3,40$ Stat. $217,219$.

68 Laurence Lustgarten \& Ian Leigh, In From the Cold: National Security and Parliamentary Democracy (Oxford: Clarendon Press, 1994); (Sir Richard Scott, "Report of the Inquiry into the Export of Defence Equipment and Dual-Use Goods to Iraq and Related Prosecutions"

69 Brad Ashwell, "Momentum Builds for Public Funding of Congressional Elections." Florida Public Interest Research Group (28 March 2007), online: Florida PIRG <http://www.floridapirg.org>.

70 Robin Ramsey, "Getting it Right: The Security Agencies in Modern Society" (2001) 41 Lobster: the Journal of Parapolitics, online: Lobster <http://www.lobster-magazine.co.uk/online/issue41/ lob41-27.htm>.

71 Makky, supra note 63. 


\section{B. Paint it Black}

Since 1949 the CIA has been operating programs 'off the books.' The 1947 National Security $\mathrm{Act}^{72}$ and the 1949 Central Intelligence Agency [CIA] Act ${ }^{73}$ allow clandestine transfers of sums between the CIA and other government agencies. This was augmented by legislation approving the secrecy over the funding mechanism used for the CIA and intelligence related activities. Indeed, there is now an official 'black budget' and an unofficial black budget. The funding of the former (of which the CIA is said to hold about 12\%) is currently about $\$ 31.5$ billion or $19 \%$ of the acquisition funding for the Department of Defense [DOD], which has been doubling in constant dollars since $1995 .{ }^{74}$ The funding of the latter is executed through mainly two vehicles: legal authority that sanctions lawful transfer of funds from a variety of federal agencies including the Department of Housing and Urban Development [HUD] (in which in the 1990 s, tens of billions of dollars annually went missing) and illegal redirection of organized crime or drug money laundering. With respect to the latter, the trial and Congressional hearings on wrongdoings by Oliver North entered into evidence personal notes regarding his role in Iran-Contra that cited \$14 million that could be raised by the Contras from the drug trade. ${ }^{75}$

The CIA's true annual budget is estimated to exceed 1 trillion dollars. This money is spread to many military intelligence agencies within the DOD and also to 'deep black projects' outside the regular appropriations and oversight process mandated by Congress. It also funds advanced weapons systems and intelligence capabilities for use against adversaries "whose existence and identity remain unknown." ${ }^{\prime 6}$ Special-access programs [SAPs], better known as "black projects" are credited with being "America's most successful intelligence operations during the Cold War" ${ }^{\text {"77 }}$ but are little known to lawmakers (sometimes fewer than 200 operatives and officials are 'read' into them). They deploy additional DOD security beyond the "baseline" of the provisions of TS-SCI or "Top Secret-Sensitive Compartmented Information" to restrict dissemination of sources and methods and "Secret, Top Secret critical restricted data" protocols within a predetermined group of people. Others in the private industry are further protected by proprietary privilege or are created behind other USAPS [Unacknowledged SAPs] or SAPs, thus comprising an extraordinary level of serial compartmentalization. Outsourced intelligence, encapsulating the many ironies

\footnotetext{
50 U.S.C. 402.

350 U.S.C. 403.

74 Steven M. Kosiak, "Classified Funding in the FY 2009 Defense Budget Request." Center for Strategic and Budgetary Assessments (17 June 2008), online: CSBA <http://www.csbaonline. org.>.; "Secrecy Report", supra note 57 at 10.

75 "The Oliver North File: His Diaries, E-Mail, and Memos on the Kerry Report, Contras and Drugs" National Security Archive Electronic Briefing Book No. 113 (26 February 2004), online: The National Security Archive, The George Washington University <http://www.gwu.edu/ $\sim$ nsarchiv/index.html>.

76 Greg Szymanski, "CIA 'Black Budget' Estimated at Over \$1.1 Trillion Per Year; Scheme to Fund Spy Group Unconstitutional But Lawmakers Don't Care" The Arctic Beacon (1 May 2005), online: The Arctic Beacon <http://www.arcticbeacon.citymaker.com/page/page/1518131.htm>.

77 Seymour M. Hersh, "The Gray Zone: how a secret Pentagon program came to Abu Ghraib" The New Yorker (24 May 2004), online: The New Yorker <http://www.newyorker.com>.
} 
of organized crime-cum-state capitalism, is now favored in the National Security Agency (NSA) and the Defense Intelligence Agency [DIA]. The percentage of the approximately $\$ 60$ billion annually spent on intelligence by the US government that goes to the private intelligence community is approximately $70 \%{ }^{78}$ The DIA has been transferring "core intelligence tasks of analysis and collection" to private companies (like Blackwater). ${ }^{79}$

Although attempts were made to correct the lack of accountability to Congress of CIA appropriations - in 1967, by constitutional challenge eventually to the Supreme Court (in 1974), ${ }^{80}$ by legislative branch challenge via the Senate Select Committee on Intelligence (Church Committee), and in 1997, by a suit won by the Federation of Atomic Scientists that the black budget could be revealed without harming national security - the CIA survived these and has consolidated its role as a funnel for the combined black budgets of DOD and the intelligence community. ${ }^{81}$

\section{Authorized Telling: Information Dissemination Processes and \\ Mechanisms}

Modulation of the faciality of 'dark' politics is provided in the maintenance of disclosures and exclusions from the information commons. Following Wilsnack, ${ }^{82}$ the obverse of secrecy is persuasion. Persuasion gains in its significance or power (to a point) with the stock of excluded knowledge from which it is drawn. If all that one knows about the war with Eurasia/Eastasia is what Big Brother releases, one's view of war and the war effort is a product of the parochialism of propaganda. If what one thinks one knows is also drawn from sources that are perceived as independent of government interests in "relatively autonomous" institutions, the propaganda potential is not diminished but enhanced.

Disclosures may be made at all levels of the intelligence hierarchy up to and including directors and politicians charged with oversight, review, or mandate directives. Disclosures may be statutory, official, or strategic. Statutory releases

78 Jeremy Scahill, Blackwater: The Rise of the World's Most Powerful Mercenary Army (New York: Nation Books, 2007).

79 The importance of the black financing does not end here. According to Catherine Austin Fitts, Coast to Coast AM, April 4, 2005, one dimension of the peculiar reorganization of US financial institutions after WWI has been the role of consortia of private banks in the Federal Reserve. As in 'public' intelligence, in 'public' finance, accounting firms and whistleblowers are in the eye of the storm. Visible is a fraction of the financial relations between large New York banks like J.P. Morgan Chase and defense contractors like Lockheed Martin, "who are running the systems of all the government departments," and may be "responsible for diverting and laundering billions of dollars every day from public and other undisclosed funds." (Fitts, 2005) For Fitts, this means that the US government has neither information nor financial sovereignty.

80 U. S. v. Richardson, 418 U.S. 166, 94 S. Ct. 2940.

81 Joël Van der Reijden, "Unacknowledged Special Access Programs" Biblioteca Pleyades (10 Sept 2005), online: Bilbioteca Plyades <http://www.bibliotecaplyades.net/sociopolitica/ sociopol_USAP.htm>. People read into Unacknowledged SAPs, or USAPs, are to deny the program's existence if questioned. 'Waived' black programs are exempt from standard reporting requirements to Congress, with only select oral notification of the existence to members of the relevant committees. One of these SAPs, Copper Green, regulated the physical and sexual humiliation of Iraqi prisoners in an "effort to generate intelligence."(Hersh, supra note 77).

82 Wilsnack, supra note 47. 
are those made to government bodies in accordance with regular or episodic review or oversight. Official releases are signed and authorized by the agency, and may include single or bundled records provided with caveats, or publicly to the media, by directors or other officials. Strategic releases may be unofficial (disinformation, counter-information), counter-strategic (where the intentional release of the information counters the official or unofficial mandates or leadership agendas), or counter-organizational (where the release, intentional or not, does not fulfill any coherent organizational or institutional agenda). Release of information that has been processed and classified, even if formerly in the public domain, is governed by a variety of legal instruments (Official Secrets legislation, non-disclosure agreements, caveats, memoranda of understanding, etc.).

Unofficial strategic releases include what is also called "white propaganda" or the dissemination of information through unofficial channels, including media outlets. As evidenced by ex-intelligence agents and informants, ${ }^{83}$ officers take up postings as journalists (from stringers to executives) and insert information into mainstream news, even to the point that distinguishing this white propaganda from 'clean copy' has troubled intelligence agencies ${ }^{84}$ Especially following the various intelligence commissions of the late 1970s, intelligence agencies were banned from pointing disinformation campaigns (also known as psychological operations or psyops) at domestic targets. However, propaganda campaigns are contracted out to private companies including the Lincoln Group and Rendon Group, the latter of which was paid to assist in the public relations campaign buttressing support for the US incursion against Iraq, and whose chief executive officer [CEO] was appointed to a secret committee to coordinate propaganda efforts: the Counter Terrorism Information Strategy Policy Coordinating Committee. This followed the release of Donald Rumsfeld's classified position document, the Information Operations Roadmap, which advanced "the goal of information operations as a core military competency" ${ }^{35}$ and sought a greater interoperability between the public affairs function and secret psychological operations ${ }^{86}$ and the shuttering of the Pentagon's Office of Strategic Influence, also tasked with planting propaganda, which apparently lives on under cover (Rumsfeld: "You can have the name, but I'm gonna keep doing every single thing that needs to be done and I have.") ${ }^{87}$

Information release decisions are made by an interpretation of security interests at a high level of insulation from democratic politics. Since information

83 Donald Goddard \& Lester K. Coleman, Trail of the Octopus (London: Bloomsbury Publishing, 1993); George Fraser, Seeing Red: Undercover in 1950s New Zealand (Palmerston North: Dunmore, 1977); Ralph McGehee, "The Indonesian Massacres and the CIA" Covert Action (02 Nov 2006), online: Covert Act <http:www.covertaction.org//content/view/156/0/>.

84 McGehee, ibid.

85 "Information Operations Roadmap" US Department of Defense (30 October 2003), online: The National Security Archive, The George Washington University <http://www.gwu.edu/ $\sim$ nsarchiv/index.html>.

86 Eric Schmitt \& Thom Shanker, "The Struggle For Iraq: Army Shift; No. 2 Army General to Move in as Top U.S. Commander in Iraq" The New York Times (25 May 2004), online: The New York Times <http://www.nytimes.com>.

87 US Department of Defense, News Transcript, "Secretary Rumsfeld Media Availability En Route to Chile" (18 November 2002), online: US DOD <http://www.defenselink.mil>. 
release serves political authority, these authorities time their dissemination of intelligence at key decision points. ${ }^{88}$ While the chief executive is constrained in dealing with the 'invisible government' (because he or she takes grave risks going directly to the people on matters of (even contested) national security), ${ }^{89}$ agencies charged with a national security mandate will selectively disclose national security information to promote a policy agenda. Politicians, up to and including prime ministers and presidents, operate knowing that disgruntled members of the 'invisible government' can undercut their purposes by leaking information. ${ }^{90}$ In the case of Maher Arar, Justice O'Connor made reference to the timing of the leaks by government officials (probably within intelligence ranks) that served to undercut the chances of a public inquiry into official wrongdoing related to Arar's torture. In another example, ${ }^{91}$ still unconfirmed, the leak to the National Enquirer of Jesse Jackson's infidelity (his 'love child') was timed to undermine gathering and unpredictable momentum in a campaign of protest against the George W. Bush inauguration. ${ }^{92}$

In March of 2007 the widow of the murdered Wall Street Journal reporter Daniel Pearl received a phone call from Attorney General Alberto Gonzales. At the time, Gonzales's role in the controversial dismissal of 8 US Attorneys had

88 Victor Marchetti \& John D. Marks, The C.I.A. and the Cult of Intelligence, 1st ed. (New York: Knopf, 1974).

89 External knowledge of security intelligence is developed on the basis of three broad types of information: authorized and unauthorized 'security leaks,' official disclosures, and security oversights.

90 David Wise \& Thomas B. Ross, The Invisible Government (New York: Random House, 1964).

91 One of Richard Nixon's most famous uses of classified information was in the lead-up to the 1960 Presidential election. Briefed on plans for the Bay of Pigs, and knowing that the invasion could not take place prior to the election, Democratic candidate John F. Kennedy suggested in a public speech that decisive action was necessary. Outraged at this use of classified information, seeing that it showed Kennedy as hawkish and knowledgeable on foreign affairs, and therefore realizing the election may hang in the balance, Nixon stated that what Kennedy was advocating was a clear breach of several treaties that the US had signed and irresponsible statesmanship. He finessed Kennedy in this way knowing that Kennedy could not disclose anything on the impending operation still under Eisenhower's presidency, one that Nixon would carry out were he elected. Similarly, the election campaign of Ronald Reagan was aided by an Italian intelligence leak published in The New Republic about President Carter's brother Billy and his business ties to Libya. It was further aided by the 'October Surprise,' a CIA-involved effort to delay the release of the American hostages, which may have involved Robert Gates, among others.

92 In Great Britain, the Wilson government was subject to a ferocious campaign of back-channel leaking. Colonel Sammy Lohan regularly leaked "scurrilous material to Pincher and others" in the attempt to bring down the government. (David Leigh, The Wilson Pilot: Intelligence Services and the Discrediting of a Prime Minister (London: Heinemann, 1988) at 107) Indeed, as Leigh recounts, the campaign against the Wilson government, involving MI5 and American intelligence, in particular James Jesus Angleton, saw 6 of the ministers he appointed accused by elements within MI5 as being Soviet spies or 'security risks.' False stories, particularly of a sexual nature, about Wilson himself were collected and circulated by officers or former officers of MI6, MI5, the CIA and the FBI. The campaign against Wilson also included leaked documents to The Times and Private Eye suggesting that after WWII Wilson was using his political position to aid Russian espionage. This was based on partially purged closed files of the Board of Trade, which, in their totality, suggested rather that Wilson was merely carrying out governmental instructions with respect to sales of British jets to Russia. (Leigh, ibid. at 37-54). 
just been exposed, and the story was becoming a scandal in Washington. Gonzales told Marianne Pearl that the Justice Department was about to announce that a terrorist in US custody - Khalid Sheikh Mohammed - had confessed to killing her husband. According to The New Yorker, "the Administration planned to release a transcript in which Mohammed boasted, 'I decapitated with my blessed right hand the head of the American Jew Daniel Pearl in the city of Karachi, Pakistan. For those who would like to confirm, there are pictures of me on the Internet holding his head." "93 However, more than three years earlier, in 2003, National Security Advisor Condoleezza Rice told Marianne the same news under the understanding it was to be kept secret. When Gonzales was asked if he had proof that Mohammed's confession was truthful he claimed to have corroborating evidence that could not be shared. ${ }^{94}$

The strategic intelligence leak exploits the modal shift of information to knowledge or the fault-line between the retention of actionable information and its dissemination in the service of deniable interests. The timed or calibrated disclosure maximizes influence because it may over-determine a preferred interpretation in the absence of the genus of facts from which it is chosen. In the meantime, authorized but un-sourced disclosures and leaks allow the security bureaucracy to continuously augment its capacity and knowledge-edge as information is published on the basis that it promotes security and intelligence agendas. This brings us to the question of how we may regard the inter-penetration of power, knowledge, and the operation of the intelligence bureaucracy and government secrecy. There are distinct, longstanding traditions that collide in the juncture between law's knowledge and the sovereign's knowledge.

\section{Executive Lawmaking: Making it Legal}

In popular understanding, law is an ordering of values encompassed in a distinction between politics and natural justice. However, 'the rule of law' in practice is a set of arcane strictures that often permanently defers an executive decision to alternative venues and other times. Realists and critical legal scholars among others have long argued a version of legal skepticism that the administration of George W. Bush has only been too happy to finesse. Perhaps more powerfully, Agamben has argued that as a legal category, emergency completes "law's

93 Jane Mayer, "The Black Sites" The New Yorker (13 August 2007), online: The New Yorker <http://www.newyorker.com>.

$94 \mathrm{Ibid}$. Sneaky governing, or governing through intelligence classification and disclosure, cannot succeed unless unauthorized disclosures are minimized. As Henry Kissinger is famous for recognizing, the power of a government's information advantage is usurped and this special modality of power is weakened when un-sourced and unauthorized leaks remain unchecked. Non-disclosure strategies include the development of proactive policies aimed at finding and stopping un-sourced, unauthorized leaks. The need to know convention limits access to intelligence information, even excluding and covering the $\mathrm{CEO}$, at least theoretically. However, the obverse is that information sources can be so successfully concealed or plugged that information can no longer be credibly vetted. Which is to say, there is much reflexivity (sometimes dangerously so) in security information management. Indeed, as McGehee, supra note 83 , and others have noted, intelligence may not be able or willing to distinguish the 'blowback' from the efforts of its own assets and un-tampered non-intelligence information sources. 
empire." ${ }^{55} \mathrm{~A}$ 'state of exception,' operating with the force of law but beyond the grasp of law, is a product not of absolutism but of democracy through the metaphor of war. It is not necessary to recount the many machinations that brought on the politics that gave the administration its 'originary authority.' The point I wish to make here is that intelligent governmentality, in addition to being deployed via the visibility of information production and circulation, is defined by its deployment of secret law. Two illustrations will hopefully suffice.

In December of 2004, the US Justice Department was publicly declaring torture as abhorrent. At almost precisely the same time, it was adopting a secret legal opinion that provided an endorsement of techniques or practices (waterboarding, sleep deprivation, sensory deprivation, head slapping, and their "combined effects") that remained classified and that the CIA wanted "legalized." ${ }^{\prime 6}$ As Michael Scheuer (chief of the Bin Laden unit under Bill Clinton and designer and manager of the rendition program) explained in an April 17 hearing before members of the House of Representatives, "[t]here is no operation at the CIA that is conducted without the approval of lawyers. It is the bane of our existence ...." ${ }^{97}$ Thus, in order to continue practices that were already idealized in Vice President Dick Cheney's "one percent doctrine" ${ }^{98}$ but were also facing congressional opposition, the new legal opinion on "combined effects" provided language to allow the CIA to continue to employ the "harshest interrogation techniques' it has ever used. ${ }^{99}$ Changes to the executive orders, including the governing of torture or interrogation, were also covered by the administration's legal position that a president "can 'waive' or 'modify' a published executive order without any public notice - simply by not following it." ${ }^{100}$ Such secret lawmaking puts legislators in the dark about the operability of published executive branch mandates.

In July of 2008, Congress passed amendments to the Foreign Intelligence Surveillance Act ${ }^{101}$ (FISA), originally enacted in 1978, following revelations in the Church and Rockefeller Commissions into illegal surveillance of Americans by the FBI and the National Security Agency [NSA]. The 2008 amendments provide immunity to telecom companies that had provided infrastructure support to illegal wiretapping of Americans by government agencies. They also roll back judicial checks on wiretapping activity, including expanding the legal parameters of data-mining and allowing for investigations of Americans based on suspicion of involvement in terrorist activities rather than probable cause. In advancing a

95 Giorgio Agamben, State of Exception (Chicago: University of Chicago Press, 2005) [Agamben, State of Exception].

96 Scott Shane, David Johnston \& James Risen, "Secret U.S. Endorsement of Sever Interrogations" The New York Times (4 October 2007), online: The New York Times <http://www.nytimes. com>.

97 Michael Scheuer, "Testimony: the Spy Who Came in From the Cold" Harpers (22 October 2007), online: Harper's Magazine <http://www.harpers.org>.

98 Ron Suskind, The One Percent Doctrine: Deep Inside America's Pursuit of its Enemies Since 9/11 (New York: Simon \& Schuster, 2007).

99 Shane, Johnston \& Risen, supra note 96.

100 Russ Fiengold, "Government in Secret" Los Angeles Times (8 May 2008), online: Los Angeles Times <http://www.latimes.com>.

10150 U.S.C. $\$ 1801$, as amended by FISA Amendments Act of 2008, P.L. 110-261 (2008). 
rationale for the bill's passage, an unnamed FBI official provided the widely cited quote, "We don't know what we don't know." 102 At the same time, according to Senator Russ Feingold, "when the Senate ... approved some broad and controversial changes to FISA, almost none of the senators voting on the bill could know what the law currently is." ${ }^{\prime 103}$ The passage of the amendments, which, on its face is a clear breach of the Fourth Amendment, occurred under a Democrat majority at a time when approval ratings for the President, the President's 'war on terror,' and Congress itself, were between 20 and 30\%.

As per the argument that security and governmentality come to be indistinguishable (following Foucault), the intersection of existential/quotidian and internal/external expands to subsume contiguous places in the body politic and then the whole power relation. Thus, justice is displaced with risk assessments, assessments passed through intelligence bureaucracy, and bureaucracy becomes a network beyond the auspices of the nation-state. Lawyers and judges are vetted through security clearances before they can bring a highly constrained version of the adversarial process into play in 'terror cases.' Loyalty checks, narrowly establishmentarian political engagement, acceptance of national security intelligence protocols, and 'myths' all work to subordinate justice to security. In addition to constraints on entry or authorship, there are alterations in the internal rules that classify, order, and distribute information between primary and secondary 'texts.' Disclosure is a prime example. Here the archive from which defense attorneys may draw up an answer to a charge is already an intelligence product that has been selected not for purposes of 'justice' but for carrying out a secret security agenda. For example, according to former Justice Department prosecutor John Loftus, the non-prosecution of al-Qaeda operatives in the US who were known to law enforcement in the 8 months prior to 9/11 was because American law enforcement and border and immigration agencies were being "blocked" and "deliberately kept in the dark and systematically prevented from connecting the dots before 9/11 in order to aid Enron's secret and immoral Taliban negotiations," specifically to secure a pipeline project through Afghanistan. ${ }^{104}$

The point that law or legalization is not an antidote to arbitrariness or the reach of exceptionalism has been often made. ${ }^{105}$ It is not so much legality but the relationship with visibility ${ }^{106}$ that best describes what might be called the cut of government by intelligence. Legal practices, as is well known, may be securitized, militarized, or intelligencified. This means that the operation of cornerstone principles (transparency, the right to confront one's accusers, disclosure, etc.) is restricted so greatly so as to leave only the imprimatur of legal propriety. ${ }^{107}$ The manipulation of political visibility through the stewarding, shepherd-

102 "Proposed FBI Plan Would Consider Racial Profiling" Los Angeles Times (3 July 2008), online: Los Angeles Times <http://www.latimes.com>.

103 Fiengold, supra note 100.

104 Ahmed, supra note 53 at 21.

105 Neocleous, supra note 13.

106 Cf. Kevin D. Haggerty \& Richard V. Ericson, eds., The new Politics of Surveillance and Visibility (Toronto: University of Toronto Press, 2006).

107 As is also well-known, the history of adversarial law may be characterized in terms of the severance of physical coercion from disclosure (cf. Green, supra note 49). That history also 
ing, and criminalizing of information-possession defers to longstanding legal traditions and institutions even as these are denuded. But the claim that the law thus achieved is constitutionally 'empty' can also be countered as a view that is weakly nostalgic. ${ }^{108}$ On the contrary, it is 'strong constitutionalism' together with economic vitality and national security that binds the courts to a significant role. The expert knowledge of legal professionals is stewarded for this view of strong government. It is already 'intelligencified' in the substitution of security intelligence for legal norms, including the protection of sources and methods and the substitution of court judgments for executive discretionary authority.

\section{E. Information Control Policing}

As Foucault argued, the "concrete form to [the] new political rationality and to this new kind of relationship between the social entity and the individual"109 was the police or Polizei. It was the police who were to define, describe, and organize this new technology of power and the new techniques of integration. Certainly in the development of many countries, police have functioned, sometimes almost to the exclusion of other institutions, as agents of governance. Consequently, it would not be surprising to find radical changes in the function of police with changes to political rationalities.

If there was a previous iteration of this function that intended to define, describe, and organize the relation between the social entity and the individual by reference to rights-bearing subjects and by weighting the authority with procedural constraints, including the very publicity of that authority, that relation would be substituted for information control. This reflects a change in what is being accomplished or attempted at the sharp end: the logic is not integrative but exclusionary. Criminals are not wrongdoers but enemies. Indeed, there is ample evidence to marshal. In broad strokes we have seen the decline of community policing and the rise of intelligence-led and intelligence-based policing,

matched the development of the modern legal subject, in particular its reliance on the putative contest between equals, the equality dividend the court was to assure or make up. However, the development above is not simply the return of the inquisition. Practices of the inquisition were situated in the middle-ages, whereas 'combined effects' interrogation is being sutured to the extant institutions of the modern liberal nation-state.

108 Intelligence bureaucracies have finessed an initial monopoly on 'national security' to further advantages accruing from the opacity of their files and the inviolability of their sources and methods. The nature of these monopolies and advantages also push the core of intelligence work in the direction of collection rather than analysis, and within this, to covert action rather than passive surveillance (cf. Marchetti \& Marks, supra note 88); Wise \& Ross, supra note 90; Jeffrey T. Richelson \& Desmond Ball, The Ties That Bind: Intelligence Cooperation between the UK/USA Countries, 2d ed. (Boston: Unwin Hyman, 1990). As a consequence, sophisticated intelligence becomes temporally and structurally aggressive, useful for intervention prior to the possibility of an undesired event occurring. Information or communications networks may accordingly be corrected, in the disciplinary sense, before they are fully operational. The finest intelligence work becomes secret action prior to the 'completion' of the (open) political process. Secret information that can serve public policy without being available to public scrutiny is the special product of intelligence agencies. When political security information has leaked out and is no longer rarefied, the operation of the institutions of liberal governance (legislatures, media, judiciary, etc.) are invited to apply a retroactive seal of approval.

109 Foucault, "Political Technology", supra note 8 at 153. 
and also of reassurance policing as a kind of policing by public relations. We have also seen, with the rise in press agents and officials in police agencies, how police have come to view their efforts in terms of the dissemination of selective information for public consumption. In a word, we have seen the absorption of law enforcement into an intelligence capacity. ${ }^{110}$

The New York Police Department [NYPD] is perhaps the leader. Instead of relying on FBI classified data from Washington the NYPD created its own classified-information vault at its headquarters, known as the Sensitive Compartmented Information Facility. It now has a Deputy Commissioner for intelligence who worked in the CIA's clandestine service and analytical division. A thousand NYPD police officers are assigned full time to operations drawing on the traditional missions of the CIA and the FBI. This includes officers posted overseas working undercover or as liaisons. It also includes developing a system of listening posts and trip wires. Essentially, New York is building state infrastructure and as a consequence is seeing like a state.

Also in the US, new guidelines allow all counterterrorism cases to be opened under the same classification number so that they can be handled from the outset like an intelligence or espionage investigation. Investigators may now easily use secret warrants and other methods overseen by the Foreign Intelligence Surveillance Court [FISC]. The FBI cases are centralized instead of being run by individual field offices and the emphasis is on monitoring or prevention not criminal prosecution. ${ }^{111}$ The system of compartmentalization has not gone unchallenged; as in Portland where the police commissioner, Mayor, and former Police Chief Tom Porter pulled their officers out of a Joint Terrorism Task Force [JTTF] because they were not granted security clearances equal to those Portland officers assigned to the JTTF and therefore could not "know what they know' and provide full oversight. ${ }^{12}$

The last illustration is the relatively recent innovation of the surge, conducted in New York, Miami, and elsewhere. In this technique, heavily armed officers are rotated into daily, randomized, highly orchestrated, and extremely visible mobilizations of force, often to sites of critical infrastructure. In these surges, pedestrians or travelers must make way for what may or may not be a public display of training. "Anybody who's bad and wants to watch to see if we're creatures of habit, we're showing them we're not. We're creating confusion." "113 "It's letting the terrorists know we are out there .... We want that shock. We want that awe." 114 The enterprise is predicated on the logic of a boundary that is already superseded:

110 See Louise Cainkar, "Introduction: Global Impacts of September 11" (2004) 24:1 Comparative Studies of South Asia, Africa and the Middle East 155.

111 Dan Eggen, "FBI Applies New Rules to Surveillance: Many Searches not Subject to Courts' Oversight" The Washington Post (13 December 2003) A01, online: The Washington Post <http:// www.washingtonpost.com>.

112 Sarah Kershaw, "In Portland Ore., a Bid to Pull out of Terror Task Force" The New York Times ( 23 April 2005), online: The New York Times <http://www.nytimes.com>.

113 Elizabeth Kolbert, "The Surge” The New Yorker (7 April 2003), online: The New Yorker <http:// www.newyorker.com>.

114 "Miami Police Take New Tack Against Terror" Associated Press (29 November 2005), online: Associated Press <http://www.ap.org $>$. 
"But at the same time, we don't want people to feel their rights are being threatened. We need them to be our eyes and ears." 115 Here, police have incorporated a new political rationality that references the previous iteration. Today police are not defining, describing, and organizing a relationship between the state and the individual in terms of the political arithmetic of the pastoral alone. Rather, they are obliquely referencing the individual as a rights-bearer in innovating new techniques that make rights-bearing an artifact or quaint object in the mis-en-scène and exploit the counter-intelligence relations of information control.

\section{F. Intelligencification Beyond the State}

Information control reproduces the presumed relation between actionable and exclusive information, ${ }^{116}$ but this is not restricted to its 'original' necessity in the state. On the contrary, we are seeing the spread of practices that are designated beyond common accessibility and accountability to other institutions and organizations. Such spread may well hit other governmental institutions before dovetailing with the privacy, confidentiality, and proprietary constructs of private industry.

First, a word about the tractability of such practices culturally. Popular media is dominated by references to dangers that are consistent with the interests of the multinational corporation that profits from the dissemination of 'news.' Where terror competes with street crime or displaces the ideological threat (communism) for newsworthiness according to these interests, the banners stoke popular fears accordingly. Selective intelligence leaks or disclosures match the dissemination agenda of information control with the profit motive of popular media. The result, as Janne Flyghed has argued, is a "false consciousness" of "impending danger." 117 Such 'governing through fear' is stimulated and one might even say modulated through the evaluation stage of the intelligence cycle. That is to say, the dosage of exclusive knowledge references that point to larger subterranean or 'gathering dangers' is a product of the interplay between the production and dissemination of intelligence products and the measurement of consumer appetites. Those consumers of intelligence product, it is well-known, may have an appetite for more than they can readily digest, and for this reason the dosage (classification, declassification) is a matter of great interest both to those who rely on existing risk distributions as well as those who may be first in line where fears or panic pushes venture and risk markets.

The modulation of classification/declassification was readily apparent with the transition from anti-communism to anti-terrorism. At the Los Alamos nuclear research facility ${ }^{118}$ there was a wave of declassification that followed the collapse of the Soviet Union that was quickly followed by a retreat into firmer and

115 Ibid.

116 Secret information is unavailable and not actionable until and unless it serves a political purpose: it is information buried within politics, rendered incapable even of supporting an alternative discourse. Its aim is the suspension or non-affordance (Mike and Still, supra note 40), even about the nature of the thing it is putatively about national security.

117 Janne Flyghed, "Normalizing the Exceptional" (2002) 13:1 Policing and Society 23.

118 Cf. e.g. Jeffrey Bussolini, "Institutional Change in Los Alamos as Emblematic of Wider Change in U.S. National Security," in Bacj Vida \& Willem de Lint, eds., Security in Everyday Life (New York: Routledge Publications) [Forthcoming in 2009]. 
harder classification following $9 / 11$. This pattern was replicated in organizations all over the world. Information of almost any kind was pulled through an intelligence lens and sorted by intelligence experts and deemed public or common or private or exclusive. Even information that was already public and broadcasted on websites was taken off and rebranded, and those continuing to disseminate it were outlawed accordingly. This exercise produced a further iteration of popular sensibilities, one that is succinctly captured with the prohibition against 'joking' about terrorism at airports. ${ }^{119}$

Within the area of border security (which includes private providers), there is a transformation from population to information as the bedrock variable. There is also the emergence of intelligence in the presentation of results or products (contraband, lookouts) of thickened and overlapping border power-relations of sovereignty, discipline, and governmentality ${ }^{120}$. For instance, the Canadian Border Security Agency (CBSA) releases information about seizures at the border in a variety of venues, including, on occasion, via a media event in which seized goods are displayed. However, the timing and selection of these displays will be vetted through intelligence expertise. Intelligence performs a sovereign exercise - in determining the timing and selection of a visible display of exclusive cutting (stoppage of goods, seizing of contraband) - and also a security-risk exercise (modulating or tempering the visibility of the cut, making a determination of threshold at which a particular action will be performed). In sum, intelligence determines the security of information for 'the commons' on the already given premise that such information may be exploited by 'enemies' on one hand, and useful for the maintenance or elaboration of intelligent systems of security, on the other.

Within other institutions we can see a more prosaic expansion of intelligence. For example, 'classificatory authority' is now available to officials in the US Department of Health and Human Services, the Environmental Protection Agency, and the Department of Agriculture. The Bush administration withheld information on consumer issues including auto and tire safety reports and limited disclosure on local environmental hazards. ${ }^{121}$ Under a proposal by that administration, the Office of Management and Budget would gain control of the release of emergency declarations from federal agencies responsible for such 'population' or quotidian concerns as public health, safety and the environment on a prior determination or weighing of the 'political hazards' ${ }^{122}$ that might attend. While it might at first blush appear that this is merely a return to command economy or totalitarian control, here we would note that information as intelligence must flow to a central conduit for evaluation before retargeting can take place. It does so because even in liberal democracies information cannot be entirely open; it must be filtered against the interests of adversaries or (as per the market) competitors.

Much of the value of security information or intelligence is gained through

119 Mark Salter, "No Joking" in Bacj \& de Lint, ibid.

120 Michel Foucault, "On Governmentality" in Graham Burchell, C. Gordon \& Peter Miller, eds., The Foucault Effect: studies in governmentality (Chicago: University of Chicago Press, 1991) [Foucault, "Governmentality"].

121 Andrew Schneider, "White House Seeks Control on Health, Safety" St Louis Post-Dispatch (11 January 2004), online: STL Today <http://www.slttoday.com>.

122 Ibid. 
the fact of its rarity, whether that is a production of analysis or of means and methods in its retrieval. For this reason, control of collection, retention, analysis, and dissemination of the intelligence cycle is key. At the same time, the co-existence of liberal democratic institutions requires that accounts be offered consistent with the stated agenda of governance. As noted, reconciling open and intelligencified governance is achieved via reference to the extraordinary or exceptional. Since 'monsters' may be measured by open techniques, the favored gambit is to point instead at 'ghosts.' Ghosts disappear and reappear at the behest of those who have access to the levers of security knowledge. ${ }^{123}$ They invite continuous interpretations about the true order of things as the 'base' of 'superstructural' relations of governance. That there is something unknown in the closet that might upend the whole house is the means used to absorb radical views about that order and keep extant politics on a security tether. That the closet has existed for so long and outlasted so many disagreements is testimony to its enduring utility.

In addition to the necessary indeterminacy or the known unknown, this closet full of secrets contains between its discrete compartments an official genealogy of the founders of the nation-state. As an executive branch archive, it is a line of guilty knowledge, a counter-law ${ }^{124}$ counter-narrative connected by the theme of official violence and founding extortion and by tales of daring gambits, farcical errors, and excesses of zeal. Each of its compartments affords limited access to the main combatants, specifically as a means to check or dress-down vainglorious or radical presumptions, again via reference to the necessary conflict of politics. Not only must the secrets of state be kept from external others who do not belong (spies) but also from internal subjects (insurgents) who seek government destabilization from within. Again, it is the principle of contest and conflict that is continuously resuscitated through this mechanism. In short, the secret utility is predicated on this notion of adversariality.

\section{INTELLIGENT GOVERNMENTALITY/SECURITY}

Most intriguing, however, was another tool for keeping the population abreast of the government's activity: the reading hut (izba-chital'nia), a humble cabin in some small, out of the way community equipped with newspapers and political pamphlets. This intended redoubt of political knowledge in the beknighted countryside has hitherto been identified only with the Bolsheviks. As we have seen however, zemstvo activists before the First World War and Whites in the course of the Civil War also established information networks for enlightening the population. And, very significantly, both Reds

123 Richard Devetak, "The Gothic Scene of International Relations: ghosts, monsters, terror and the sublime after September 11" (2005) 31:4 Review of International Studies 621; Willem de Lint, "The Security Double-Take: The Political, Simulation and the Border" (2008) 5:2 Surveillance and Society 166.

124 Richard V. Ericson, Crime in an Insecure World (Cambridge: Polity Press, 2007). 
and Whites described their task not as 'propaganda' but as 'enlightenment'. The propaganda state, or more accurately, the Enlightenment state, was not solely a Bolshevik ideal. ${ }^{125}$

What may be added by seeing intelligence as a distinct modality of rule or governmentality? What happens when information control turns common knowledge into exclusive knowledge and agonistic into antagonistic relations? In the quote above, Holquist refers to the implementation at the beginning of the $20^{\text {th }}$ century in 'large scale' of a particular type of modern governmental politics called the national security state through, among other devices, various techniques of 'patriotic instruction' called 'enlightenment activity.' Today, the metaphor of an information outpost for a random proliferation of 'white propaganda' may well be on the wane. Now a relatively autonomous intelligence network is a vast labyrinth, peeping out from under a mountain of classified information. The metaphor may be augmented with James Bamford's ${ }^{126}$ compelling image of an 18-wheel tractor-trailer in the underground caverns of the NSA taking a daily tonnage of paper off to the underground incinerators. ${ }^{127}$ The intelligence challenge is to preserve for the right moment, and from this fate, the two or three documents that might change the world. Intelligencification is the contouring of political rationality through the practices and ideological/discursive principles of information control.

Under intelligencification, information control is not only the practice but also the ideology of politics. At the same time that the practice of state security services is tied more to the interests of the political party in power or (partisan) politics, the methods and objects of leading political parties begin to mimic security services. Policy plans are vetted according to multiple audience profiles, and there are a variety of disclosures including unofficial leaks. ${ }^{128}$ Disclosure discretion or secrecy competes with and more often trumps the claims of open government. Under such terms as "the unitary executive" and "sensitive compartmentalized intelligence" (a Cheney initiative) government decision-making is rendered more opaque from without and within the bureaucracy. In short, intelligencification is the projection of the exclusionary logos, or the necessity of social and political exclusions and exclusive authority, into the internal rationality of government.

As governmentality, intelligence is the art of matching the particular mythic or discursive orientations of a political authority to the generic, popular orientations of the nation-state; it cuts information into exclusive executabilities. Intelligence offers logic and place to exceptionalism and means beyond political visibility to show off the power of the executive function of the nation-state.

125 Peter Holquist, “'Information is the Alpha and Omega of Our Work': Bolshevik Surveillance in its Pan-European Perspective" (1997) 69:3 The Journal of Modern History 415 at 423.

126 James Bamford, Body of Secrets: anatomy of the ultra-secret National Security Agency from the Cold War through the dawn of a New Century, 1st ed. (New York: Doubleday, 2001).

127 According to the Office of Management and Budget, between 2001 to 2007, the US government increased its spending on paper shredding by $587 \%$.

128 Jasminka Kalajdzic, "Access to Justice for the Wrongfully Accused in National Security Investigations" Windsor Y.B. Access Just. [forthcoming in 2009]. 
Defenders of the nation-state itself or its existential interest ('il faut defendre la societé') deploy the capacity to make the cut between friend and foe, an act that is prior to law or legitimacy or the requirement to reveal sources and methods. In addition, and against the trend toward a hegemony of effects and the fragmentation and recombination of biosecurity, it reconstitutes the individual subject along the lines of sovereign political constituency and existential and ideological threats. This presents a context for the openness many intelligence agencies are claiming they are now subjecting themselves to, through such devices as the publishing of annual reports. Intelligence is 'going public' as the discourse and logic of secrecy is becoming politically fashionable. The 'security apparatus' produces an intelligence anti-politics in which cloaked or secret knowledge justifies, penetrates, and sometimes overturns popular sovereignty.

In this new era of juggernaut modernity and hyper-reflexivity, ${ }^{129}$ black sites, black programs (including surveillance), and black budgets are known unknowns: we know they are there gathering inertia and pushing and pulling the political. However, these pushes and pulls cannot be fully hypothesized by their effects. In the operation of this kind of power, which engages deferred reference to exclusive information and to exceptional and legal capacities, conduct and even 'true' or 'best' knowledge about conduct is itself a significant object of the information control agenda. What is readily accessible or hits the surface begs the question of the agendas and agencies that shape the subterranean battlefield to recreate that dark foundation in a particular image of order.

Security as a discourse and intelligence as a practice have developed in the context and on the back of subjugated knowledge. However, the vantage point to assess that subjugation as a social fact is itself a victim, not only of the proliferation of security and intelligence in governmentality (inasmuch as this produces deliberate structural limits of access to relevant archives, etc.), but also of the analytical and epistemological preferences that will disbelieve the integrity of the archivist, her standpoint, her ability not to reproduce or recreate the very subjugations that animate her desire and work. If the archival method uses the subtracted discourses rather than the narrative of the victor, it might also be asked if the files informing conclusions about the problem of rule is one the vanquished has the capacity to peruse.

Lifted to the register of government policy, intelligence is a system of double exclusions. In other words, knowledge and expertise in addition to being productive of subjectivities and identities is also prohibitive. This is to stress that ignorance or 'fearful knowledge' can be positively produced as a consequence of the distribution of access to information resources. In what has been described as the 'low visibility' of police discretion, police refer to the informational, legal, or coercive resource in order to take action without transparency or review. Through the intelligence function, security officials prohibit identities by vetting and keeping a governmental information advantage; by reference to a body of information and the capacity to deploy it officials can maintain the boundaries of politics for an established political authority. The information advantage is particularly important today as access to institutions is key and vetted reputa-

129 Giddens, supra note 23. 
tions through security clearances are of growing importance. Information here is also subtly connected to coercion, as reference to information, real or not, may be sufficient to break sound identities and undercut credit or credibility. At a higher register, the occasional leak or disclosure acts as a reminder of this stock of information and helps to freeze political movement or redefine a political constituency.

Am I suggesting a retreat from the 'productive' scaffolding of power/knowledge? Rather perhaps hybridization. On one hand, we see the proactive distribution of knowledge to shape, privatize, and 'enlighten' subjects. On the other, practices of ordering are contingent upon or follow the affirmation of exclusivity or othering and the division of the political according to adversarial power relations. Together, these inform the character of governance as sneaky or endarkened. Like dark matter, what has been called 'invisible' or 'secret' government ${ }^{130}$ may also be credited with a powerful capacity to govern conduct.

Intelligencification's material practices may be viewed against its undermining of national security as a basis for sovereign, exceptional, and exclusive power manipulations. The insulation and decoupling of intelligence bureaucracies from political executives, especially as security intelligence bureaucracies cross-cut 'national' jurisdictions, means that the sovereign referent or justification is often threadbare; it merely matches a risky economic vitality to the highly mobile transnational. It fosters the further collapse of the Westphalian accord and protocols pertaining to external versus internal ordering. In another sense, however, it requires the exposure of those processes and practices (intelligent control) to a further iteration of consent recovery: now at the level of transnational auspices. For this, a new enlightenment hut is no doubt under construction to meet the public relations requirements of the global wilderness. It will be a source of light that might illuminate the beneficence of a new supranational sovereign entity, one that exploits a new pastoral or police science to draw together practices of security modulation and the separation and combination of a variety of mined 'dividual' components and- most difficultly - their linkage to a new view of totality. ${ }^{131}$

All of this being said, our conceptualization has cornered us. We can take the weakened position that exclusion, exception, and the executive guardian role of security intelligence must each be checked by the rule of law in the particular, rather than the generic. That is to say, against the Agamben reading, the totality of petty inclusions into the normative sleeve produces a condition closer to the liberal idealist than the liberal realist position. ${ }^{132}$ On the contrary, we can take the hard position following that long line of thinkers into the Frankfurt school, ${ }^{133}$ that under the condition of liberal capitalism it will always be the decisive role of the executive to break the norm in the service of power brokers already 'in the room' of the executive decision-maker. What is missing is a per-

130 Marchetti \& Marks, supra note 88; Wise \& Ross, supra note 90.

131 Here Doran usefully reminds us that transnational security is more complex, heterogenous, unpredictable, and unaccountable than national security. See Charles F. Doran, "Why Forecasts Fail: the limits and potential of forecasting in international relations and economics" (2002) 1:2 International Studies Review 11.

132 Cf. Neocleous, supra note 13.

133 For example see Scheureman, supra note 25. 
spective that is most easily discredited in any of the human sciences, one that speaks to what we do not and cannot know. And this is the perspective most relevant as the true 'subordinated' of intelligence: since intelligence is about the constraint of knowledge discovery according to a cautious political stasis or spy$\mathrm{v}$-spy rapprochement, it is the conditions on the 'will to truth' and the stipulations on authorized knowing that are fundamental; however, it is exactly the indeterminacy or unknown of the life-condition that is most significant to the evaluation of the existential (and necessary exclusions). If the only important exclusion is death, then the nature of death is that unknown absent the measure of which security intelligence can have no social and political utility. In other words, pace Foucault, the archive is the "a priori of discursive practices that give existence determinate form," 134 but contra Foucault, it is not all we need to know, or rather, it is the beginning of what we need to know, if 'we' are not to be reduced to discursive effects.

One last observation: I originally drafted this paper with a vignette about Jesse Jackson's reversal of fortune in the lead-up to Bush's inauguration on January 20, 2001. The National Inquirer published an article 48 hours before Bush's inauguration that claimed that the leader of the Rainbow Coalition had a secret, 'love child' with a woman to whom he was not married, a revelation that decapitated the Rainbow Coalition and led immediately to Jesse Jackson announcing his retirement from politics. The point of the vignette is obvious. Visible politics is modulated by agents and agencies of intelligence and this strategic modulation has intended and unintended consequences. One consequence that is not necessarily unintended is the charge against those who see agency behind strategic revelations as 'conspiracy theorists.' This charge can be bolstered by muddying the waters by exploiting the release of intelligence to media that also report on unidentified flying objects [UFOs]. A second (intended) impact of such releases, especially in their precise timing and startling impact, operates much like an execution spectacle: akin to a 'coded' message to politically knowledgeable others who may wish to enter the fray, the release is a statement that 'the political' is not as open as it may appear to be; it is a discouragement of politics as a limitless possibility, in the Arendtian reading. This leaves us with a liberal democracy (or political rationality) that has become conditioned by intelligence and the technologies of autocracies or plutocracies.

\section{CONCLUSION}

Vice President Cheney came up to see the Republicans yesterday. You can always tell when the Republicans are getting restless, because the Vice President's motorcade pulls into the Capitol, and Darth Vader emerges. ${ }^{135}$

There is no doubt that governance is increasingly calibrated to the security

134 Ronjon Paul Datta, "Politics and Existence: totems, dispotifs, and some striking similarities between Durkheim and Foucault" (2008) 8:2 Journal of Classical Sociology 283 at 283.

135 Hillary Clinton, "Hillary Clinton Calls Cheney 'Darth Vader'", online: Breitbart TV <http://www.breitbart.tv/html/5815.html> 
problem, but while it is often understood that governments collect information to promote the policies they want to pursue, it may be argued that a less visible or shadow government operates by proactive negation. It promotes the policies it wants to pursue through the selective disclosure of information, the timing and quality of which will help ensure the implementation of a pre-cleared agenda. Therefore, governance through the apparatus of security, but the dissemination of the security agenda through the bureaucratic restriction of knowledge, both in the production of secrecy and in the calibrated disclosure or strategic security leak. This is a modality that utilizes a monopoly over the modal shift of information to knowledge: the fault-line between the retention of actionable information and its disclosure in the service of public policy. Meaning may then be overdetermined as the genus of facts from which 'leaks' are chosen remains opaque. Information is selected for disclosure by the security apparatus to augment its capacity and knowledge and a double system of exclusions. ${ }^{136}$ In the meantime, the whole apparatus of information control is articulated to legal provisions in an iterative adaptation of what law may come to allow.

When the National Inquirer reported on the 'love child,' popular media may have been instrumentalized by intelligence assets to modulate the conduct of conduct. Since information control is exercised not only in what is concealed but also in the logistics of the disclosure, intelligencification entails the actioning by governing authority or its imprimatur, of strategically collected information (via security clearances, secret collection, etc.). Intelligencification encompasses the justification of dark site practices in executive and domestic domains (in a recursive double play), the moving of exceptionalist goal posts, the substitution of legal knowledge practices ('legal truth,' mechanisms guaranteeing a record of coercion) for intelligence knowledge practices ('best truth' or market sensitive dissemination ${ }^{137}$ ), the displacement of accountability with periodic intelligence products, the compartmentalization of government auspices (the CIA program allows no external access from outsiders, is made up through a disassembled mosaic), and the absolute priority, founded on the exclusive cut, of nondisclosure of means and methods (on the grounds that such disclosure is 'aid and comfort' for 'the enemy').

Dean points out that governmental rationalities work through "desires, aspirations, interests and beliefs." 138 Here I hope to have begun to demonstrate that the large body of knowledge concealed beneath the surface of those aspirations and desires (not to mention fears) is comprised of a 'dark figure' of actionable information and active subterranean agents: all-too calculating on the param-

136 Police networks, the 'secret state' bureaucracy, and the trans-national intelligence bureaucracy in particular add a further dimension to how we may think of coercion and the locus of power. Indeed, we tend to think in terms of an institutional separation between a military sphere of knowledge production and a civil sphere of knowledge, but information traffic between civil society and police and military knowledge undermines the distinction. What the military bureaucracy adds to the equation is essential because it is explicitly about the maintenance of information boundaries and boundedness. Coercion takes place with the reference to actionable secret knowledge, be it specified or kept as generic.

137 In the field of security politics 'truth' is the product that matches market to mission. Actually, the practices are 'legalized' through the displacement of contrary legal opinion.

138 Supra note 10 at 11. 
eters of the political; all-too effective in forcing course corrections to the ship of state. Indeed, and following the optics of power after Lukes and Foucault, ${ }^{139}$ intelligent governmentality throws off effects as part of a logic of concealment. The dirty secret ${ }^{140}$ is not merely the violent pedigree of law or the state and the necessity of the exclusionary cut. It includes the whole array of 'national security' instruments that create and recreate knock-off governmental rationalities. Thus if it can be said that one can find appearances behind interests or effects behind ideologies, it can also be said that one may stop interpretations at a particular juncture, at the material instead of the discursive, in the play of geopolitical interests instead of an indefinite circulation of security modulation. The deployment of archives in a fixing of facts around a position is indeed the realm of intelligence, a particular reading up of desires, interests and beliefs. The dirty secret is that in the justification of further and deeper intelligencification there is no 'there' there: no requirement of 'real' terrorists, no true effort to identify what a terrorist is, no desire to get behind the mask and begin again.

In pointing out a mode of governance by which barriers of access are maintained through information monopolization, my use of the term 'endarkenment' is not simply nostalgia for a false vision of enlightenment. ${ }^{141}$ Much of this monopolization relates to identities and the use of transnational security hierarchies (and/or networks) to delimit the range of political representation of targeted classes of persons, interests, and whole ideologies. The imagery of darkness is deliberate to call attention to the idea that one can recast the view that knowledge and truth are sutured to power. It is to be remembered in this context that much knowledge is being privatized and converted into intellectual property, with limitations, use restrictions, etc. Such movements have not escaped policing and security, and indeed the privatization of security and its knowledge cannon is hardly of passing importance given its significance to subjectivities like 'citizen.' And while it is not my intention to suggest a one-on-one relationship between 'public freedoms' and open discourse, it is important to allow that some structures of knowledge representation are more pro-active in disallowing cross-checking by others. To put it metaphorically, an iceberg is partially visible floating ice, but it is the large invisible segment that scrapes the hulls of ships sending them to the bottom of the sea.

139 Steven Lukes, Power: A Radical View (London: MacMillian, 1974); Peter Digeser, "The Fourth Face of Power" (1992) 54 Journal of Politics 977.

140 See Brighenti, supra note 37.

141 Here Gertrude Himmelfarb's The Roads to Modernity: the British, French, and American enlightenments, 1st ed. (New York: Knopf, 2004) distinguishes American Enlightenment in its belief in the utter imperfectiblity (rather than the Enlightenment's perfectibility) of man and ties this to the more cautious realist posture recently abandoned in American foreign policy. 